\title{
Reasoning, Affectivity and School Performance at the end of Portuguese Elementary Education: Which Variables To Consider?
}

\author{
Cristina Costa-Lobo ${ }^{1}$ \\ Joana Matamá ${ }^{2}$ (D) \\ Daniela Nascimento ${ }^{2}$
}

\begin{abstract}
Elementary education is a stage in which children and adolescents develop reasoning and affectivity, variables often associated with school performance. This study aims to analyze the relationship between reasoning, affectivity and school performance in Portuguese and Mathematics, considering sociodemographic, relational and academic characteristics. In a non-probabilistic sample of 226 ninth graders from three different Portuguese basic schools, we collected sociodemographic, relational and academic data, and applied instruments to assess reasoning and affectivity. The results show correlation between reasoning, affectivity, school performance, parental education and quality of relationships with parents, teachers and classmates. We found differences in reasoning, affectivity and school performance based on gender, retention history, liking for school and study activities; however, there was no verification of difference regarding variables such as having separated parents, having siblings or practicing leisure activities in spare time. These results should be considered as to develop interventions to promote academic success in students who are in their final year of elementary education.
\end{abstract}

Keywords: reasoning, emotions, academic achievement, elementary education

\section{Raciocínio, Afetividade e Rendimento Escolar no Final do Ensino Básico Português: Que Variáveis Considerar?}

\begin{abstract}
Resumo: O ensino básico é uma etapa na qual crianças e adolescentes desenvolvem o raciocínio e a afetividade, variáveis associadas ao rendimento escolar. Este estudo tem como objetivo estudar a relação entre raciocínio, afetividade e rendimento escolar em Português e Matemática, tendo em consideração caraterísticas sociodemográficas, relacionais e escolares. Numa amostra não-probabilística de 226 alunos do $9^{\circ}$ ano de três escolas básicas portuguesas, foram recolhidas medidas sociodemográficas, relacionais e escolares, e aplicados instrumentos para avaliar o raciocínio e a afetividade. Os resultados evidenciam correlações entre raciocínio, afetividade, rendimento escolar, escolaridade dos pais e qualidade dos relacionamentos com pais, professores e pares. Foram encontradas diferenças no raciocínio, afetividade e rendimento escolar, mediante o gênero, histórias de retenção, gosto pela escola e pelo estudo, não se verificando diferenças mediante variáveis como ter pais separados, ter irmãos, ou praticar atividades nos tempos livres. Estes resultados devem ser tidos em consideração em intervenções para a promoção do sucesso escolar em alunos que estejam no último ano do ensino básico.
\end{abstract}

Palavras-chave: raciocínio, emoções, rendimento escolar, ensino fundamental

\section{Razonamiento, Afectividad y Rendimiento Escolar al Final de la Educación Básica Portuguesa: ¿Qué Variables a que Tener en Cuenta?}

\begin{abstract}
Resumen: La enseñanza básica es una etapa en la que niños y adolescentes desarrollan el razonamiento y los afectos, variables asociadas al rendimiento escolar. Este estudio tiene como objetivo estudiar la relación entre razonamiento, afectividad y rendimiento escolar en Lengua Portuguesa y Matemáticas, teniendo en cuenta las características demográficas, relacionales y escolares. De una muestra no probabilística de 226 estudiantes en el $9 .^{\circ}$ grado de la secundaria en tres escuelas portuguesas, se tomaron medidas sociodemográficas, educativas y relacionales, y se aplicaron instrumentos para evaluar el razonamiento y la afectividad. Los resultados evidencian correlaciones entre raciocinio, afectividad, rendimiento escolar, escolaridad de los padres y calidad de las relaciones con padres, profesores y pares. Se encontraron diferencias en el razonamiento, afectividad y rendimiento escolar, mediante el género, historias de retención, gusto por la escuela y por los estudios, no verificándose diferencias mediante variables como tener padres separados, tener hermanos, o practicar actividades en el tiempo libre. Estos resultados deben tenerse en cuenta en las intervenciones para promover el éxito escolar en los alumnos que se encuentren en el último grado de la educación básica.
\end{abstract}

Palabras clave: razonamiento, emociones, rendimiento escolar, enseñanza de primer grado

${ }^{I}$ Cátedra UNESCO de Juventude, Educação e Sociedade; Optimus Creative and Technology School, Centro de Investigação, Desenvolvimento e Inovação, IESF, Fafe, Portugal

${ }^{2}$ Universidade Portucalense Infante Dom Henrique. Porto, Portugal

Correspondence address: Cristina Costa-Lobo. Instituto de Estudos Superiores de Fafe, Rua Universitária - Apartado 178 - Medelo 4820-909, Fafe-Porto, Portugal. E-mail: cristinalobo@iesfafe.pt
School plays an important role in the lives of children and adolescents (Rocha et al., 2011), being responsible for the learning process in the acquisition of skills and knowledge (Rocha et al., 2011; Wang \& Eccles, 2013) and preparation for everyday needs (Spinath, Eckert, \& Steinmayr, 2014; Wang \& Eccles, 2013). The learning process depends on 
the interaction between characteristics of the individual and the context in which he or she is inserted (Lourenço \& De Paiva, 2010), demanding effort in order to achieve academic success (Lourenço \& De Paiva, 2010; Silva \& Duarte, 2012). This theme is currently a dominant concern throughout the literature, justifying studies that analyze factors associated with academic performance and success (Prata, BarbosaDucharne, Gonçalves, \& Cruz, 2013; Silva \& Duarte, 2012). As such, this study seeks to analyze some factors that seem to influence learning and school performance, namely sociodemographic, familiar and academic characteristics and, in particular, reasoning and affectivity, which have appeared in several studies as two interconnected, fundamental factors.

Reasoning is associated in several studies with intelligence (Almeida \& Lemos, 2005) and it constitutes a cognitive ability that both influence the learning process and explain school performance (Almeida \& Lemos, 2005; Furnham \& Monsen, 2009; Lemos, Almeida, Guisande, \& Primi, 2008; Lourenço \& De Paiva, 2010; Silva \& Duarte, 2012; Spinath et al., 2014; Valentini \& Laros, 2014). Thus, these studies become justified as to understand the cognitive functioning of students (Almeida \& Lemos, 2005).

There are several factors that influence reasoning, mainly affectivity (M. Ferreira \& Nelas, 2006; Franco \& Rodrigues, 2014; Pinto, 2005a, 2005b, 2015), which will be further addressed. Age is another associated factor, and there is evidence that older students perform worse in reasoning tests (Almeida, Lemos, Guisande, \& Primi, 2008). Retention history also seemed to be associated with a decline in cognitive abilities (Almeida et al., 2008). In a study by Spinath et al. (2014), it was found that women had higher reasoning scores, particularly at the verbal level, which could be explained by the greater effort, self-discipline, motivation and adaptation to the school. It is important to note that although there is also evidence in this and other studies of men presenting greater benefit in mathematical and spatial reasoning, the magnitude of the effect of these differences has decreased over time. Liking for school, a factor associated with student motivation, leads to the engagement in school activities, thus promoting the development of cognitive skills (Lourenço \& De Paiva, 2010). In another study, it was observed that having parents with higher literary qualifications was a contributing factor to family environments in which there was demand and commitment regarding school activities, which influenced the cognitive development of children (Alves, Lemos, Brito, Martins, \& Almeida, 2016).

Affectivity arises in several studies as complementary to cognition in the school context (Dell' Agli \& Brenelli, 2015; Pereira \& Abib, 2016; Pinto, 2015), thus emerging the interest in the study of how affectivity is associated with reasoning, since the promotion of positive affectivity in students seems to support the development of their reasoning (A. Costa \& Faria, 2013; Franco \& Rodrigues, 2014) and, consequently, their school performances (Almeida \& Lemos, 2005; Lemos et al., 2008; Valentini \& Laros, 2014).

Affectivity is much more than the sum of emotions (Souza, Petroni, \& Andrada, 2013), consisting of the ability that individuals have to be positively or negatively affected (Pereira \& Abib, 2016), based on the meaning attributed by them to experiences (Wortmeyer, Silva, \& Branco, 2014). As such, it should be seen as subjective, influenced heavily by the sociocultural context (Galinha \& Pais-Ribeiro, 2005a, 2005b). It is important to distinguish two types of affection: positive, which provides moments of pleasure, and negative, which concerns moments of displeasure (Galinha, Pereira, \& Esteves, 2014; Zanon, Bastianello, Pacico, \& Hutz, 2013).

There are several factors that can condition affectivity, such as a liking for study activities, associated with student motivation, which leads to pleasure in performing school activities, thus fostering more positive emotions (Lourenço $\&$ De Paiva, 2010). The positive affectivity of students is also influenced by the quality of the relationship with parents (Chan et al., 2013), teachers (Chan et al., 2013; Silva \& Duarte, 2012) and classmates (Farley \& Kim-Spoon, 2014). In the literature, we also found that affectivity is influenced by gender, and there is a tendency for young women to present greater negative affectivity (Carvalho, Baptista, \& Gouveia, 2004; Ciucci et al., 2017).

Concerning school performance specifically, it is important to address two curricular disciplines, Portuguese and Mathematics, which are considered nuclear disciplines in the Portuguese curricular plan and should be the target of learning evaluations throughout primary education (C. A. Ferreira, 2015). In the literature, there are several considered factors that can influence the school performance of students, and this should be seen as a subjective process that varies based on the context in which the student is inserted, as well as at the level of the various factors that may interfere (Furnham \& Monsen, 2009), such as adaptation and school experience, student effort, teaching methods, educational policies, curriculum programs, teacher-student relationship, family attitudes towards school, interpersonal relationships and intelligence (Silva \& Duarte, 2012). In another study, it was noted that female students without retentions had a higher school performance (Spinath et al., 2014). It was also found that those students that felt motivated to study and to attend school became more involved, leading them to have better school performances (Lourenço \& De Paiva, 2010; Spinath et al., 2014). Still, in a study by Raposo et al. (2011), it was found that the adjustment of the children and, consequently, school performance, did not depend directly on whether parents were separated or divorced, but on factors such as family conflicts and parental competence, maintenance of financial well-being and the psychological adjustment of parents. The presence of siblings is understood as a contributing factor to a better learning process and academic success (Alvarez \& Lemos, 2006). The practice of extracurricular activities also contributes to academic success (A. Costa \& Faria, 2013).

Several studies show that cognitive abilities are positively associated with school performance (Almeida \& Lemos, 2005; Lemos et al., 2008), that is, students with greater cognitive development learn more effectively, presenting better performance, especially in the disciplines of Languages 
and Mathematics (Valentini \& Laros, 2014). The expression of positive affection, such as pleasure, joy, satisfaction, curiosity, or creativity, influences logical-mathematical reasoning, leading to better performances in Mathematics (Mattos, 2012). On the other hand, higher levels of negative affectivity lead students to demanding school trajectories, causing them to dedicate themselves and strive more to achieve good school performances (Oliveira \& Soares, 2011). Also better relationships with parents and teachers are associated with better results of affectivity and attitude towards school (Chan et al., 2013; Silva \& Duarte, 2012). Greater involvement of parents in school education is also an important factor to consider and contributes to academic success of children (M. Costa \& Faria, 2017). Furthermore, greater concern from parents becomes an encouragement for adaptive functioning and academic success by students (Emerich, Carreiro, Justo, Guedes, \& Teixeira, 2017). Relationships between peers also contributes to the development of affectivity (Farley \& KimSpoon, 2014), as well as to reasoning (Furrer, Skinner, \& Pitzer, 2014).

Based on a literature review, there was verification of numerous factors associated with a higher school performance, including affectivity and reasoning. Considering this contextualization, we proposed as a study goal to comprehend in which ways affectivity and reasoning relate to school performance in Portuguese and Mathematics for ninth graders, the final year of primary education in the Portuguese system. We weighted sociodemographic, relational and academic characteristics, seeking to provide information as for variables that might be considered in the development of programs aiming towards promoting cognitive and affective development, as well as academic success, in such an important life cycle.

\section{Method}

\section{Participants}

Participants of this study constituted a non-probabilistic sample of 226 ninth graders, recruited through a convenience sampling process, in three public schools in Portugal, in the school year 2016/2017. Participants aged between 12 and 18 years old $(M=14.53 ; S D=0.85)$, most of them female (57.1\%). As for the household, most participants lived with their parents $(86.5 \%)$, and in relation to the remaining $13.5 \%$, parents were separated or do not live together. Most participants reported having at least one sibling $(80.1 \%)$.

\section{Instruments}

As intended, a questionnaire with sociodemographic, relational and academic issues, developed by the researchers, was applied to collect information on gender, age, characteristics of parents (age, schooling, profession), characterization of the household, history of retentions, liking for school and study, quality of relationships (parents, siblings, teachers, colleagues), frequency of leisure activities and school classifications to Portuguese and Mathematics (in Portugal ranging from 1 to 5). The answers to this questionnaire could be dichotomous (yes/no), multiple choice or in the case of the quality of relationships on an ordinal five-point scale.

To assess reasoning capacity, we used the Bateria de Provas de Raciocinio (BPR), version 7/9, developed in 2005 by Almeida et al., which proposes to evaluate cognitive abilities, specifically of fifth and seventh graders in this scenario. (Almeida \& Lemos, 2015). This version consists of five tests, namely abstract, numerical, verbal, mechanical and spatial reasoning, requiring planning and preparation for its application. The grading for each test is made through the sum of the score obtained in each item, allowing for a global mark (Almeida \& Lemos, 2015).

To evaluate affectivity, we used the Escalas PANAS De Afecto Positivo Y Negativo Para Niños Y Adolescentes (PANAS-N), developed by Sandín (2003), and measured to the Portuguese population by Carvalho et al., in 2004. This instrument consists of 20 items, which are grouped into two dimensions, positive and negative affectivity, with 10 items each, and the answers are given on an ordinal scale of three points, ranging between 1 ("never") and 3 ("often"). Its grading is performed through the sum of the items, and higher scores represent a higher rate of positive or negative affectivity (Carvalho et al., 2004). In this study, it was found that this instrument presents a good internal consistency in Cronbach's alpha, ranging from .78 , in positive affectivity, to .80 , in negative affectivity.

\section{Procedure}

Data collection. Taking into account the objectives of this study, a quantitative methodology was adopted for data collection, carried out in three primary schools in Northern Portugal during the 2016/2017 school year when the third cycle was being taught. Data were collected between February 20 and March 15, 2017, in the classroom context, in circumstances previously agreed upon with the teachers.

Data analysis. Data were analyzed using the Statistical Package for the Social Sciences (SPSS) v. 23.0. For the characterization and description of the sample, frequency and descriptive statistics (mean and standard deviation) were used, adding skewness and kurtosis to test possible violations of normal distribution. In view of the sample size $(N=226)$ and the fact that almost all variables assume a normal distribution, parametric tests were chosen, namely the T-student for independent samples and the study of differences, and the Pearson correlation test, for the study of associations. However, when the analysis encompassed ordinal variables, such as school classifications, parental education, and how participants qualified the relationship with parents, siblings, teachers and colleagues, we opted for the use of nonparametric tests, namely the Mann-Whitney test, for the study of differences, and Spearman's correlation test for the study of associations. The significance level considered was $95 \%(p<.05)$ 


\section{Ethical Considerations}

This study was approved by the Ethics Committee of the Universidade Portucalense, in Portugal, with subsequent authorization from the board of basic schools of two groups in the district of Porto, Portugal, proceeding only with participants who had informed consent from their guardians.

\section{Results}

Starting by characterizing the variables under study, it is observed that the positive affectivity of the participants has an average of $23.5(S D=3.19)$, while negative affectivity is $16.2(S D=3.55)$. The total reasoning of the students is, on average, $2.61(S D=.67)$, while abstract reasoning presents higher values $(M=2.70 ; D P=.82)$, and numerical reasoning presents lower values $(M=2.48 ; S D=.84)$. Regarding classification in schools, $50.0 \%$ of students are at sufficient level at Portuguese, and $40.3 \%$ have an insufficient level in Mathematics. In terms of relationship with parents, the participants, for the most part, reported having a very good relationship with both their father $(61.5 \%)$, and with their mother $(76.1 \%)$. Of those who reported having siblings, $50.9 \%$ consider their relationship to be very good. Academically, most participants do not have a retention history (73.9\%), have a liking for school (68.1\%), but do not like to study $(62.8 \%)$. Most consider the relationship with teachers to be good $(65.0 \%)$, and with classmates to be good $(46.9 \%)$ or very good $(44.7 \%)$.

In order to describe differences using specific characteristics (gender, retention history, liking for school and study) between the variables under analysis, the T-test for independent samples was used. Statistically significant differences were found, verifying that women have higher levels of negative affectivity $(t(220)=4.17 ; p<.001)$ and total reasoning $(t(224)=2.06 ; p=.041)$. Students with a retention history showed lower levels of total reasoning $(t(223)=4.29 ; p<.001)$, as well as lower scores in verbal $(t(222)=2.74 ; p=.007)$ and spatial reasoning $(t(221)=$ $2.79 ; p=.006)$. Students who mention liking their school showed a higher total reasoning $(t(224)=2.74 ; p=.006)$ and spatial reasoning $(t(222)=2.49 ; p=.014)$. As for students who mention liking studying, they show higher scores of positive affectivity $(t(220)=2.71 ; p=.007)$.

To compare school classifications through gender, retention history, and liking for school and study, the Mann-Whitney test was conducted, noting that the classifications in Portuguese are higher among female participants $(U=4498,500 ; p<.001)$, that do not have a history of retentions $(U=3175,500$; $p<.001)$, like the school $(U=4105,000 ; p=.002)$ and like to study ( $U=4685,000 ; p=.008$ ). The same is true with the classifications in Mathematics, which assume higher values in female participants $(U=5089,000 ; p=.019)$, that do not present prior retentions $(U=3495,000 ; p=.003)$, that like the school $(U=4305,000 ; p=.010)$ and like to study $(U=3982,000$; $p<.001)$. In addition to the abovementioned, differences associated with having separated parents and having siblings were also investigated, and no significant differences were found in terms of reasoning, affectivity and school classifications.

For the study of associations, the Pearson Correlation Test ( Table 1) was conducted, through which it was found that age correlates negatively with total reasoning $(r=-.313$; $p<.001)$ and with its verbal dimensions $(r=-.195 ; p=.003)$ and spatial $(r=-.148 ;=.027)$. Analyzing the associations between reasoning and affectivity, it was found that spatial reasoning correlates negatively with negative affectivity $(r=-.134 ; p=.047)$. It is important to emphasize that all correlations assume a low magnitude.

Table 1

Pearson Correlations for Age, Reasoning and Affectivity

\begin{tabular}{|c|c|c|c|c|c|c|c|c|}
\hline \multirow[b]{2}{*}{ Variable } & \multicolumn{6}{|c|}{ Reasoning } & \multicolumn{2}{|c|}{ Affectivity } \\
\hline & Abstract & Verbal & Spatial & Numeric & Mechanic & Total & Positive & Negative \\
\hline Age & -.125 & $-.195^{* *}$ & $-.148^{*}$ & -.089 & -.010 & $-.313^{* * *}$ & .067 & .104 \\
\hline \multicolumn{9}{|l|}{ Reasoning } \\
\hline Abstract & & $.224^{* *}$ &. $\mathbf{3 0 3}^{* * *}$ & $.218^{* *}$ & $.264^{* * *}$ & $.444^{* * *}$ & .029 & -.058 \\
\hline Verbal & & & $.260^{* * *}$ & $.255^{* * *}$ & $.212^{* *}$ & $.512^{* *}$ & .130 & -.106 \\
\hline Spatial & & & & $.361^{* * *}$ & $.135^{*}$ & $.527^{* * *}$ & .044 & $-.134^{*}$ \\
\hline Numeric & & & & & $.280^{* * *}$ & $.542^{* * *}$ & .007 & -.009 \\
\hline Mechanic & & & & & & $.419^{* * *}$ & .030 & .015 \\
\hline Total & & & & & & & .048 & -.083 \\
\hline \multicolumn{9}{|l|}{ Affectivity } \\
\hline Positive & & & & & & & & -0.19 \\
\hline
\end{tabular}


The association between the classifications obtained in the disciplines of Portuguese and Mathematics with affectivity and reasoning was analyzed through the Spearman Correlation Test (Table 2). Higher classifications at Portuguese presented a positive correlation with negative affectivity $(r s=.255 ; p<.001)$, with total reasoning $(r s=.193 ; p=.004)$ and with its verbal $(r s=.156 ; p=.020)$, spatial $(r s=.161 ; p=.016)$ and numerical dimensions $(r s=.212 ; p=.002)$. Higher classifications to Mathematics were positively correlated with positive affectivity $(r s=.160$; $p=.018)$, with total reasoning $(r s=.301 ; p<.001)$ and with its abstract $(r s=.281 ; p<.001)$, verbal $(r s=.191 ; p=.004)$, spatial $(r s=.281 ; p=.001)$, numeric $(r s=.227 ; p<.001)$ and mechanic $(r s=.155 ; p=.020)$ dimensions . All correlations found in this scope have a low magnitude.

In order to complement these findings, we chose to explore the existence of associations between parents' schooling and how participants qualify the relationship with parents, siblings, teachers and colleagues with the variables reasoning, affectivity and classifications to Portuguese and Mathematics, using the Spearman correlation test (Table 3.) As such, it was found that the father's schooling varies between the primary and secondary education and positively correlates with total reasoning $(r s=.170 ; p=.013)$, numerical reasoning $(r s=.149 ; p=.031)$ and mechanical reasoning $(r s=.161 ; p=.019)$. The mother's schooling equally varies between primary and secondary education, and was positively correlated with total reasoning $(r s=.161$; $p=.017)$ as well as numerical reasoning $(r s=.155 ; p=.013)$. It was observed that the quality of the relationship with the father is positively correlated with positive affectivity $(r s=.318 ; p<.001)$ and with the classification in Mathematics $(r s=.151 ; p=.027)$; likewise the quality of the relationship with the mother was positively correlated with positive affectivity $(r s=.187 ; p=.005)$ and with classification in Mathematics $(r s=.155 ; p=.021)$. The quality of the relationship with siblings was not associated in a statistically significant way with any variable under study. In turn, the quality of the relationship with teachers was positively correlated with positive affectivity $(\mathrm{rs}=.185 ; \mathrm{p}=.006)$, and with the classifications in Portuguese $(r s=.251 ; \mathrm{p}<.001)$ and Mathematics $(\mathrm{rs}=.237 ; \mathrm{p}<.001)$. The quality of the relationship with classmates presented a positive correlation with positive affectivity $(r s=.232 ; p<.001)$ and with verbal reasoning $(r s=.143 ; p=.032)$.

Table 2

Spearman's Correlations of School Performance in Portuguese and Mathematics with Reasoning and Affectivity

\begin{tabular}{|c|c|c|}
\hline & \multicolumn{2}{|c|}{ School performance } \\
\hline Variable & Portuguese & Mathematics \\
\hline \multicolumn{3}{|l|}{ Reasoning } \\
\hline Abstract & .056 & $.281^{* * *}$ \\
\hline Verbal & $.156^{*}$ & $.191^{* *}$ \\
\hline Spatial & $.161^{*}$ & $.281^{* * *}$ \\
\hline Numeric & $.212^{* *}$ & $.227^{* *}$ \\
\hline Mechanic & .087 & $.155^{*}$ \\
\hline Total & $.193^{* *}$ & $.301^{* * *}$ \\
\hline \multicolumn{3}{|l|}{ Affectivity } \\
\hline Positive & .065 & $.160^{*}$ \\
\hline Negative & $.255^{* * *}$ & .126 \\
\hline
\end{tabular}

Table 3

Spearman's Correlations of Parental Schooling and Quality of Relationship with Parents, Siblings, Teachers and Colleagues with Affectivity, Reasoning and School Performance in Portuguese and Mathematics

\begin{tabular}{|c|c|c|c|c|c|c|c|}
\hline \multirow{2}{*}{ Variable } & \multicolumn{2}{|c|}{ Schooling level } & \multicolumn{5}{|c|}{ Relationship quality } \\
\hline & Father & Mother & Father & Mother & Siblings & Teachers & Classmates \\
\hline \multicolumn{8}{|l|}{ Reasoning } \\
\hline Abstract & .065 & .003 & -.011 & .011 & -.002 & .019 & .044 \\
\hline Verbal & .078 & .122 & .029 & .009 & -.050 & .032 & $.143^{*}$ \\
\hline Spatial & .067 & .020 & -.014 & -.018 & -.014 & .066 & -.017 \\
\hline Numeric & $.149^{*}$ & $.155^{*}$ & -.090 & -.006 & -.045 & .061 & .036 \\
\hline Mechanic & $.161^{*}$ & .129 & -.074 & -.035 & -.135 & .014 & .016 \\
\hline Total & $.170 *$ & $.161^{*}$ & -.088 & -0.19 & -.105 & .007 & .002 \\
\hline \multicolumn{8}{|l|}{ Affectivity } \\
\hline Positive & -.073 & -.027 & $.318^{* * *}$ & $.187^{* *}$ & .095 & $.185^{* *}$ & $.232^{* * *}$ \\
\hline Negative & -.097 & -.053 & -.081 & .032 & -.061 & -.062 & .047 \\
\hline \multicolumn{8}{|c|}{ School performance } \\
\hline Portuguese & $.171^{*}$ & .082 & .057 & .031 & .008 & $.251^{* * *}$ & .055 \\
\hline Mathematics & .079 & .069 & $.151^{*}$ & $.155^{*}$ & .093 & $.237^{* * *}$ & .113 \\
\hline
\end{tabular}

Note. $p<.05 ;{ }^{* *} p<.01 ;{ }^{* * *} p<.001$ 


\section{Discussion}

In this study, it was found that reasoning in ninth graders follows values similar to those presented in the literature (Almeida et al., 2008). Similarly, positive and negative affectivity showed values similar to normative values for the Portuguese population (Carvalho et al., 2004). This ensures us that, regarding reasoning and affectivity, the sample can be considered representative of the student population.

The results further explicit, while still minding the low magnitude of the correlations, that the older the students were while attending the last year of the third cycle, the lower were their scores in total reasoning, specifically in verbal and spatial reasoning. This finding corroborates the results obtained by Almeida et al. (2008), which reported that older students perform worse in reasoning tests. In this study, a significant percentage of students with retention histories were included; when compared to the rest, these students presented a worse total reasoning, as well as a worse verbal and spatial reasoning, corroborating the considerations in the literature that, when evaluating students from a single study cycle, older students tend to have previously failed that grade, leading to the idea that low cognitive abilities influence retention (Almeida et al., 2008).

Women presented higher total reasoning, corroborating the sociocultural representation that women have a higher general intelligence, possibly supported by higher levels of effort, self-discipline, motivation and adaptation to the school, while men did not assign as much importance to school performance, nor did them demonstrate the same level of commitment (Spinath et al., 2014). Still in the topic of gender differences, there was evidence that women have higher levels of negative affectivity, corroborating the data found in a study conducted with Portuguese youth (Carvalho et al., 2004), as well as a more recent study held in Italy (Ciucci et al., 2017).

Another result that is evidenced is that having a liking for study is associated with a superior positive affectivity, while liking for school is associated with a higher total reasoning, in particular, spatial reasoning. A possible explanation is related to another construct not addressed in this study, motivation, which helps in clarifying the fact that students with a liking towards study or school take advantage of and engage in school activities, thus promoting the development of their competencies, while students who do not like to study and/or their school show a lack of interest in such tasks (Lourenço \& De Paiva, 2010).

Regarding school performance in Portuguese and Mathematics, the best results arise from female students, that do not present a retention history, who like their school and to study, corroborating the study by Spinath et al. (2014). This observation is supported by the fact that students who like to study and/or school become more involved in school activities, leading to them performing better in this area (Lourenço \& De Paiva, 2010).

There was no evidence of differences in reasoning, affectivity and school performance regarding students in the sample having their parents separated or divorced, having siblings, or practicing activities in their spare time. Regarding the fact that differences between students considering their parents' marital status could not be verified, the literature shows that adjustment of school-age adolescents is not directly related to their parents being separated or divorced, but rather through other aspects; factors such as parental competence, maintenance of familiar financial well-being and the parents' psychological adjustment may all be included and were not controlled for in this study. Nevertheless, the results of this study contradict studies that state that the presence of siblings contributes to better learning and school success (Alvarez \& Lemos, 2006), as well as contradicting studies that state that extracurricular activities contribute to better social and emotional learning and school success (A. Costa \& Faria, 2013). One possible explanation is that there are numerous factors that might influence school performance, such as adaptation and school experience, student effort, teaching methods, educational policies, curriculum programs, the teacher-student relationship, attitudes of the family towards the school, interpersonal relationships, or intelligence, among others (Silva \& Duarte, 2012).

In the association studies, it is evident a negative correlation between negative affectivity and spatial reasoning, maintaining, from the outset, that affectivity is related to the development and organization of reasoning (Pinto, 2005a). Specifically in relation to spatial reasoning, characterized by spatial cognitive organization, Mattos (2012) indicates that it relates to expression of affections such as pleasure, joy, or satisfaction, which makes sense with the indication of the expression of negative affectivity impairing spatial reasoning. Regarding school classifications in Portuguese and Mathematics, it is verified that they are positively correlated with reasoning, corroborating several studies that demonstrate positive correlations between cognitive abilities and school performance (Almeida \& Lemos, 2005; Lemos et al., 2008). This maintains that those students with greater cognitive development learn more effectively, presenting better performance, especially in the disciplines of languages and Mathematics (Valentini \& Laros, 2014). In this analysis, it was also verified that the classifications to Mathematics are positively associated with positive affectivity. One possible explanation is that the expression of positive affection, such as pleasure, joy, satisfaction, curiosity, or creativity, relate to logical-mathematical reasoning, which can lead to better performances in this discipline (Mattos, 2012). On the other hand, it was observed that the classifications to Portuguese are positively correlated with negative affectivity, that is, the expression of negative affections, such as stress, guilt, fear, nervousness and concern. In this sense, a plausible explanation suggests that these higher levels of negative affectivity lead students to demanding school trajectories, which is turn leads them to devote themselves and to work harder, in order to achieve a good school performance (Oliveira \& Soares, 2011), however, the level of school requirements and its relationship with affectivity were not controlled in this study.

At an exploratory level, associations with parents' school qualifications and how students perceive the quality of the relationship established with parents, teachers and 
colleagues. The results show that a higher education on the father's side is associated with a better school performance in Portuguese and greater total reasoning, in specific numerical and mechanical reasoning, while a higher education on the mother's side is associated with higher levels of total reasoning, in particular numerical reasoning. These results corroborate that parents with higher levels of literary qualifications provide better conditions in which more there are significant levels of expectation, demand and commitment, leading, consequently, to greater involvement with the school life of children, which promotes better cognitive and intellectual development (Alves et al., 2016; M. Costa \& Faria, 2017; Emerich et al., 2017; Prata et al., 2013). Another result that stands out is that the perception of better relationship with parents being associated with a higher positive affectivity and better classifications in Mathematics. On the other hand, the perception of a better relationship with teachers is associated with higher positive affectivity and better classifications in Portuguese and Mathematics. These results corroborate that better relationships with parents and teachers are associated with a positive expression of affectivity and more positive school attitudes (Chan et al., 2013), maintaining that the teacher-student relationship and the family approach towards the school are important for academic success (Silva \& Duarte, 2012). On the other hand, a perception of better quality of the relationship with classmates is associated with a higher positive affectivity and a higher verbal reasoning capacity, testifying that the relationship between peers contributes to the development of emotions and affection (Farley \& Kim-Spoon, 2014), as well as for the learning process and the development of reasoning (Furrer et al., 2014).

The various findings mentioned become the main contribution of this study, since it allows us to understand the importance of personal, familiar and socioacademic variables, especially reasoning and affectivity, as promoters of school performance of students who are at the end of the primary education and amidst a transition period. Therefore, the results found should be taken into account in interventions aimed at promoting academic success and the well-being of students, since they reveal which variables should be taken into account. Another relevant contribution of this study is that it brings another perspective to education, an area in need of constant updates, given its relevant role in human development, as well as by the way it is in constant change, which is visible in the constant revisions of curriculum programs.

This study does present some limitations, namely data collection through a non-probabilistic sampling process, using only students from three public schools in a single county. In this sense, we suggest that only stratified and random sampling processes of Portuguese students, both from public and private schools, should be contemplated. Because this was a cross-sectional study, we were not allowed to observe the development and effects of the variables over a given period of time, which could provide a clearer perspective of the variables under study. Another important limitation to consider in future studies is to control for the socioeconomic level of students.
In the midst of the discussion, the relevance of future studies emerged to contemplate variables such as self-efficacy, selfesteem, self-concept, personality traits and motivation, which seem, in the literature, associated with school performance. Regression studies would be equally important to analyze the effect of the variables studied on school performance.

Taking into account the results found, in a constantly evolving teaching environment, variables such as affectivity, reasoning, familiar and socioacademic environments cannot be neglected in promoting academic success for the students, so that they can become adults with the ability to assume responsible citizenship.

\section{References}

Almeida, L. S., \& Lemos, G. C. (2005). Aptidões cognitivas e rendimento académico: A validade preditiva dos testes de inteligência [Cognitive aptitudes and academic achievement: The predictive validity of intelligence tests]. Psicologia, Educação e Cultura, 9(2), 277-289.

Almeida, L. S., \& Lemos, G. C. (2015). Bateria de provas de raciocínio: Manual técnico. [Battery of evidence reasoning: Technical manual]. Braga, Portugal: Universidade do Minho.

Almeida, L. S., Lemos, G., Guisande, M. A., \& Primi, R. (2008). Inteligência, escolarização e idade: Normas por idade ou série escolar? [Intelligence, schooling and age: Norms by age or grades?]. Avaliação Psicológica, 7(2), 117-125.http://pepsic.bvsalud.org/scielo.php?script=sci arttext\&pid $=$ S1677-04712008000200002

Alvarez, A., \& Lemos, I. C. (2006). Os neurobiomecanismos do aprender: A aplicação de novos conceitos no dia a dia escolar e terapêutico [The neurobiomechanisms of learning: The use of new concepts at school and therapeutic setting]. Revista Psicopedagogia, 23(71), 181-190. Retrieved from http://pepsic.bvsalud.org/scielo. php?script $=$ sci_arttext\&pid $=$ S0103-84862006000200011

Alves, A. F., Lemos, G. C., Brito, L., Martins, A. A., \& Almeida, L. S. (2016). Desempenho cognitivo na infância: A mãe e o meio urbano fazem a diferença [Cognitive performance in childhood: Mother and urban environment make the difference]. Psicologia: Teoria e Pesquisa, 32(3), e32317. doi:10.159/00102-3772e323217

Carvalho, M., Baptista, A., \& Gouveia, J. (2004). Análise da estrutura factorial de uma medida de auto-avaliação da afectividade negativa e positiva para crianças e adolescentes. [Analysis of the factorial structure of a measurement selfassessment of negative and positive affectivity for children and teenagers]. In C. Machado, L. S. Almeida, M. Gonçalves, $\&$ V. Ramalho (Eds.),Actas da X Conferência Internacional de Avaliação Psicológica: Formas e Contextos. Braga, Portugal: Psiquilíbrios Edições.

Chan, C. S., Rhodes, J. E., Howard, W. J., Lowe, S. R., Schwartz, S. E. O., \& Herrera, C. (2013). Pathways of influence in school-based mentoring: The mediating role of parent and teacher relationships. Journal of School Psychology, 51(1), 129-142. doi:10.1016/j.jsp.2012.10.001 
Ciucci, E., Baroncelli, A., Tambasco, G., Laurent, J., Catanzaro, S. J., \& Joiner, T. E., Jr. (2017). Measuring positive affect, negative affect, and physiological hyperarousal among Italian youth: Translations of the PANAS-C and PH-C. Journal of Psychopathology and Behavioral Assessment, 39(3), 373-382. doi:10.1007/ s10862-017-9596-8

Costa, A., \& Faria, L. (2013). Aprendizagem social e emocional: Reflexões sobre a teoria e a prática na escola portuguesa. [Social learning and emotional: Reflections on theory and practice in Portuguese school]. Análise Psicológica, 31(4), 407-424. doi:10.14417/ap.701

Costa, M., \& Faria, L. (2017). Parenting and parental involvement in secondary school: Focus Groups with adolescents' parents. Paidéia (Ribeirão Preto), 27(67), 28-36. doi:10.1590/1982-43272767201704

Dell'Agli, B. A. V., \& Brenelli, R. P. (2015). Reações afetivas em sala de aula: Situação lúdica e tarefa escolar. [Affective reactions in the classroom: Playful situation and school task]. Schème: Revista Eletrónica de Psicologia e Epistemologia Genéticas, 7(1), 133-148. Retrieved from http://www2.marilia.unesp.br/revistas/ index.php/scheme/article/view/5321/3730

Emerich, D. R., Carreiro, L. R. R., Justo, A. M., Guedes, P., \& Teixeira, M. C. T. V. (2017). Sociodemographic characteristics, behavioral problems, parental concerns and children's strengths reported by parents. Paidéia (Ribeirão Preto), 27(67), 46-55. doi:10.1590/1982-43272767201706

Farley, J. P., \& Kim-Spoon, J. (2014). The development of adolescent self-regulation: Reviewing the role of parent, peer, friend, and romantic relationships. Journal of Adolescence, 37(4), 433-440. doi:10.1016/j. adolescence.2014.03.009

Ferreira, C. A. (2015). A avaliação das aprendizagens no ensino básico português e o reforço da avaliação sumativa externa. [Learning assessment in Portuguese basic education and the reinforcement of external summative assessment]. Educação e Pesquisa, 41(1), 153-169. doi:10.1590/S1517-97022015011892

Ferreira, M., \& Nelas, P. B. (2006). Adolescências... adolescentes. [Teens... teenagers]. Millenium, 32, 141162. Retrieved from https://revistas.rcaap.pt/millenium/ article/view/8399/5990

Franco, G. R., \& Rodrigues, M. C. (2014). Programas de intervenção na adolescência: Considerações sobre o desenvolvimento positivo do jovem. [Software intervention in adolescence: Considerations about the positive development of young people]. Temas em Psicologia, 22(4), 677-690. doi:10.9788/TP2014.4-01

Furnham, A., \& Monsen, J. (2009). Personality traits and intelligence predict academic school grades. Learning and Individual Differences, 19(1), 28-33. doi:10.1016/j. lindif.2008.02.001

Furrer, C. J., Skinner, E. A., \& Pitzer, J. R. (2014). The influence of teacher and peer relationships on students' classroom engagement and everyday motivational resilience. Teachers College Record, 116(13), 101-123.
Galinha, I. C., \& Pais-Ribeiro, J. L. (2005a). Contribuição para o estudo da versão portuguesa da positive and negative affect schedule (PANAS): I - Abordagem teórica ao conceito de afecto. [Contribution for the study of the Portuguese version of positive and negative affect schedule (PANAS): I - Theoretical approach to the concept of affection]. Análise Psicológica, 23(2), 209-218. doi:10.14417/ap.83

Galinha, I. C., \& Pais-Ribeiro, J. L. (2005b). Contribuição para o estudo da versão portuguesa da positive and negative affect schedule (PANAS): II - Estudo psicométrico. [Contribution to the study of the portuguese version of positive and negative affect schedule (PANAS): II Psychometric study]. Análise Psicológica, 23(2), 219. 227. doi:10.14417/ap.84

Galinha, I. C., Pereira, C., \& Esteves, F. (2014). Versão reduzida da escala de afecto positivo e negativo portuguesa - PANAS-VRP: Análise factorial confirmatória e invariância temporal [Short-Form of the Portuguese version of the positive and negative affect schedule PANAS-Port-VRP: Confirmatory factorial analysis and temporal invariance]. Psicologia, 28(1), 50-62. Retrieved from http://www.scielo.mec.pt/scielo.php?script=sci arttext\&pid=S0874-20492014000100005

Lemos, G., Almeida, L. S., Guisande, M. A., \& Primi, R. (2008). Inteligência e rendimento escolar: Análise da sua relação ao longo da escolaridade. [School intelligence and performance: Analysis of your relationship throughout schooling]. Revista Portuguesa de Educação, 21(1), 8399. Retrieved from http://www.scielo.mec.pt/pdf/rpe/ v21n1/v21n1a05.pdf

Lourenço, A. A., \& De Paiva, M. O. A. (2010). A motivação escolar e o processo de aprendizagem [Motivation and school learning process]. Ciências \& Cognição, 15(2), 132-141. Retrieved from http://pepsic.bvsalud.org/scielo.php?script=sci arttext\&pid=S1806-58212010000200012

Mattos, S. M. N. (2012). O desenvolvimento do raciocínio lógicomatemático: Possíveis articulações afetivas. [The development of reasoning logical-mathematical: Possible affective joints]. Caderno Dá Licença, 7(10), 89-102. Retrieved from http:// www.dalicenca.uff.br/images/artigo5.pdf

Oliveira, M. B., \& Soares, A. B. (2011). Auto-eficácia, raciocínio verbal e desempenho escolar em estudantes [Self-efficacy, verbal reasoning and school performance of pupils]. Psicologia: Teoria e Pesquisa, 27(1), 33-39. doi:10.1590/S0102-37722011000100005

Pereira, M. M., \& Abib, M. L. V. S. (2016). Memória, cognição e afetividade: Um estudo acerca de processos de retomada em aulas de física do ensino médio [Memory, cognition and affectivity: A study about processes of recalling during High School physics classes]. Ciências da Educação, 22(4), 855-873. doi:10.1590/1516-731320160040003

Pinto, F. E. M. (2005a). A afetividade na organização do raciocínio humano: Uma breve discussão [The affectivity in the organized of the human reasoning: Abrief reflection]. Psicologia: Teoria e Prática, 7(1), 35-50. Retrieved from http://pepsic.bvsalud.org/scielo.php?script=sci arttext\&pid=S1516-36872005000100004 
Pinto, F. E. M. (2005b). Os (des)afetos da inteligência: O possível diálogo entre cognição e afetividade. [The (dis) affects of intelligence: The possible dialogue between cognition and affectivity]. Publicatio UEPG: Ciências Humanas, Linguística, Letras e Artes, 13(1), 7-12. doi:10.5212/publ.humanas.v13i1.530

Pinto, F. E. M. (2015). Cognição e afeto: Uma primeira visão reflexiva sobre $\mathrm{o}$ funcionamento do sujeito psicológico. [Cognition and affection: A first reflective view on the functioning of the psychological subject]. Revista da Educação, 8(8), 61-69. Retrieved from https://revista.pgsskroton.com/index.php/educ/article/ viewFile/2212/2107

Prata, A., Barbosa-Ducharne, M., Gonçalves, C., \& Cruz, O. (2013). O impacto dos estilos educativos parentais e do desenvolvimento vocacional no rendimento escolar de adolescentes. [Impact of parenting educational styles and of vocational development in school performance of teenagers]. Análise Psicológica, 31(3), 235-243. doi:10.14417/S0870-8231201300030002

Raposo, H. S., Figueiredo, B. F. C., Lamela, D. J. P. V., Nunes-Costa, R. A., Castro, M. C., \& Prego, J. (2011). Ajustamento da criança à separação ou divórcio dos pais [Child adjustment to separation or divorce of parents]. Revista de Psiquiatria Clínica, 38(1), 29-33. doi:10.1590/ S0101-60832011000100007

Rocha, A., Marques, A., Figueiredo, C., Almeida, C., Batista, I., \& Almeida, J. (2011). Evolução da saúde escolar em Portugal: Revisão legislativa no âmbito da educação. [Evolution of school health in Portugal: Legislative review in the field of education]. Millenium, 41, 69-87. Retrieved from http://www.ipv.pt/millenium/Millenium41/6.pdf

Sandín, B. (2003). Escalas PANAS de afecto positivo y negativo para niños y adolescentes (PANASN). [PANAS scales of positive affect $\mathrm{y}$ negative for children and adolescents (PANAS-N)]. Revista de Psicopatología y Psicología Clínica, 8(2), 173-182. doi:10.5944/rppc. vol.8.num.2.2003.3953

Silva, D. M., \& Duarte, J. C. (2012). Sucesso escolar e inteligência emocional. [School success and emotional intelligence]. Millenium, 42, 67-84. doi:10.13140/RG.2.1.1614.1923

Souza, V. L. T., Petroni, A. P., \& Andrada, P. C. (2013). A afetividade como traço da constituição identitária docente: $\mathrm{O}$ olhar da psicologia [Affectivity as an aspect of teachers' identity constitution: A view from psychology]. Psicologia \& Sociedade, 25(3), 527-537. doi:10.1590/ S0102-71822013000300007

Spinath, B., Eckert, C., \& Steinmayr, R. (2014). Gender differences in school success: What are the roles of students' intelligence, personality and motivation? Educational Research, 56(2), 230-243. doi:10.1080/001 31881.2014.898917

Valentini, F., \& Laros, J.A. (2014). Inteligência e desempenho acadêmico: Revisão de literatura [Intelligence and academic achievement: Literature review]. Temas em Psicologia, 22(2), 285-299. doi:10.9788/TP2014.2-02
Wang, M.-T., \& Eccles, J. S. (2013). School context, achievement motivation, and academic engagement: A longitudinal study of school engagement using a multidimensional perspective. Learning and Instruction, 28, 12-23. doi:10.1016/j.learninstruc.2013.04.002

Wortmeyer, D. S., Silva, D. N. H., \& Branco, A. U. (2014). Explorando o território dos afetos a partir de Lev Semenovich Vigotski [Exploring the territory of affects based on Vygotsky's legacy]. Psicologia em Estudo, 19(2), 285-296. doi:10.1590/1413-737223446011

Zanon, C., Bastianello, M. R., Pacico, J. C., \& Hutz, C. S. (2013). Desenvolvimento e validação de uma escala de afetos positivos e negativos [Development and validation of a positive and negative affect scale]. Psico-USF, 18(2), 193-202. doi:10.1590/S1413-82712013000200003

Cristina Costa-Lobo is a Coordinating Professor at the Institute of Higher Studies in Fafe (IESF), Portugal.

Joana Matamá is a Researcher of the Universidade Portucalense Infante D. Henrique (UPT), Portugal.

Daniela Nascimento is a Professor of the Universidade Portucalense Infante D. Henrique (UPT), Portugal.

\section{Authors' Contribution:}

All authors made substantial contributions to the conception and design of this study, to data analysis and interpretation, and to the manuscript revision and approval of the final version. All the authors assume public responsability for content of the manuscript.

Received: Jan. 19, 2018

1st Revision: Apr. 04, 2018

2nd Revision: Jun. 25, 2018

3rd Revision: Oct. 02, 2018

4th Revision: Jan. 30, 2019

Approved: Mar. 26, 2019

How to cite this article:

Costa-Lobo, C., Matamá, J., \& Nascimento, D. (2020). Reasoning, affectivity and school performance at the end of portuguese elementary education: Which variables to consider?. Paidéia (Ribeirão Preto), 30, e3008. doi:http:// dx.doi.org/10.1590/1982-4327e3008 